\title{
Ideas sobre las imágenes y el mito.
}

El mundo de las imaigenes es un mundo de presencias vivientes que agita un soplo desconocido y misterioso. Como las velas en el mar, vienen, van, se pierclen y reaparecen para detenerse en la rada silenciosa del alma. No sabemos por qué se van ni por qué vuelven. Son gratuitas, puras $y$ escuivas; $y$ aunque navegamos en toclas ellas siempre nos parecen lejanas y como si entre sus formas radiantes y nosotros se interpusiera, infrancueable, el abismo.

\section{Biblioteca de Letras}

Las cosas persisten, las imágenes pasan. O mejor, las cosas son núcleos sólidos que se mantienen los mismos a través de todos los cambios de coloración o de perspectiva en que nuestra mirada los contempla mientras que las imágenes se dan una vez y ya no vuelven. Los árboles, los ríos, las rocas que componen un paisaje, quedan, permanecen en la inconmutable realidad de su existencia, y yo puedo dejarlos en mi infancia y volver a encontrarlos en mi vejez; pero yo no puedo resucitar en ese conjunto la misteriosa palpitación de la luz de tál crepúsculo, la seducción de un minuto de ftrgaz armonía, las imágenes en fin que llenaron de color $y$ de vida el escenario de la naturaleza. Aparecieron y fugaron como las luces inciertas de la noche. 
Lats imágenes son asi cumm lat pied cambiante, multicoior e impalpable de las cosas.

Las cosats som, las imbigenes parecen. Cuando yo me renetentro en presencia de una cosil admito que ella existe fuera de mi contemplacion, que es algo silido, aparte, en si. Cuaido yo me extasio ante una inagen, no sé si ella existe " no existe fuera de mi contemplacion. Sólo sé que lia veo. Que lat cusas son quiere decir que yo puedo tomarlas, dejarlas o incluso destruirlas, pero siempre y de todos modos que las cosals se afirman como algo distinto de su mera aparición. Que la imagen parece significa que ella no existe sino porrute es contemplialia, porque hay un alma que es como el ligar metafisico te sti padiante fantasmatgoria.

Así se dibuja un dualismo o más exactamente una oposicion entre las cosas y las imágenes, entre el munde de lat existencia en que las cosis permanecen y el mundo de la apa riencia en que las imágenes fulgen, pasan y se clisipan.

Pero hay más: Como quiera que el munclo de las inágenes es un egriunto de visiones que cual velo de Naya encubren el mundo de las cosas, et dialismo entre cosas e

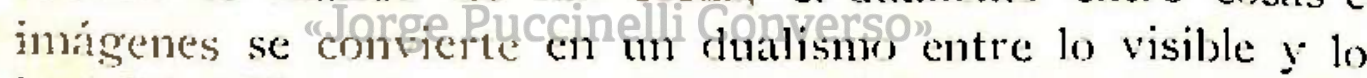
invisible. $Y$ ocurre que en esa oposición mientras crece la jurisclicción de lo invisible se va apagando poes a poco hasta extinguirse la laz de las imagenes.

Para la mente primitiva hay entre lo visible $y$ lo invisible una cierta relación de polaridad, de suerte que siendo opuestos son inseparables. Para la mente primitiva toclo lo que se ve es un signo de lo que no se ve, pero que no lo encubre simplemente ni lo disimula como ana máscara, sino que lo expresa y encarna, del mismo modo que el cuerpo hamano es la expresión viviente, la imagen auténtica del alma. Asi torlo to invisible es visible y todo lo visible está lleno de 
una misteriosa palpitación, de algo oscuro, inclecible, proiunclo, de algo en fin que a través de las varias imágenes propaga el ritmo universal de la vicla.

El pensamiento abstracto, en cambio, descleña las imígenes y en un progresivo trabajo de eliminación llega a concebir el mundo como un sistema de relaciones matemáticas, sistema que es la culminación de la vieja tendencia metafísica, que a partir de la forma pura de Aristóteles, pasanclo por la razón cartesiana y la sustancia de Spinoza, quisiera encerrar en una fórmula simple, pura de todo resto sensible, la realidad suprema, la última esencia de las cosas.

Mas este desinterés por la imagen como tal, es clecir por la imagen como simple aparecer, como pura visión, no es exclusivo de la actividad teórica. Lo encontramos también en el dominio de la activíclad práctica, es decir en ei dominio de la actividad que utiliza las cosas, que se sirve de ellas para la realización de fines, puesto que servirse de una cosa es prescindir de su mera aparición para retener tan sólo su aspecto utilizable, su función; y la función es invisible ya que no se da Cenala imagen misma sino que se adhiere a ella porJvirtud de Con lo cual las cosas pierclen su coloración y su incividualiclad para incorporarse en los esquemas abstractos de la acción y más propia y específicamente de la técnica.

De este modo por el trabajo combinado del pensamiento abstracto y de la actividad práctica, el universo no es ya un conjunto de imágenes sino un' sistema de relaciones invisibles, que la tcoría concibe ora como ecuaciones, ora como fuerzas, ora como puras formas de la mente y que la activiclad práctica utiliza no reteniendo de la concreta policromía de lo real sino los elementos inclicativos de una función posible, de un servicio posible. 
Así se apaga lat lu\% de las imágenes $y$ asi finalmente queda aboliclo el senticlo de la vision y, con de, un conjunto de experiencias ritales necesartias no sólo para la economía interior del alna sino también para la fecundidad $y$ la armonía superior del espíritu.

Por todo lo cual acaso llega el tiempo de reivindicar la importanciat de lo visible y de su espontáneo, gratuito florecer.

Hemos dicloo que las imágenes son la piel de las cosas; sólo que a veces se desprenden y vuelan y se adhieren a otras cosas, o se fragmentan y disipan e, uniéndose a otros fragmentos errantes, componen figturas inesperadas. Hay en ciertas zonas indecisas ded alma tun gran aleteo de formas dispersas, y el alma misma o es quićn sabe otra cosa que lat ley iguorada de su composición. De esta suerte con las formas inéditas, con los fantasmas que no corresponden ya a to antes vistibsugecen el alume que fos crea y contempla un reino mágiore gle Glusión yi manaxillio

Es tun reino de presencias vivientes donde tudo cambia, florece y se marchita. Mundo polícromo en que todo es diverso y en que todo está suspendido en el mismo soplo animador. Mundo de los sueños lo flamariamos, no porque to confinemos en el circulo de las visiones que pucblan la noche del hombre dormido, sino porque, contraponiéndose al pensamicnto abstracto y a la acción ntilitaria, se nos ofrece con toda la riqueza, la vida y csa como flotante irrealidad de los sueños.

Nuestra atención, o más exactamente, nuestro sentimiento de la realidad y cle la vida oscilan entre un paisaje de 


\section{$-9-$}

imágenes, de sueños y un mundo incoloro de abstracciones, entre un abandono a las visiones gratuitas espontáneas e inagotables de la vida y una actitud de reflexión, de crítica que sustrayéndonos a ese abandono, nos mantiene distintos, separados y firmes, en fin nos mantiene como cosas en medio a una encantada fulguración de apariencias.

Este abandono del alma a la visión, este embriagarse en el torrente sin fin de las imágenes es, tomando esta palabra en su acepción más primitiva, el éxtasis.

El éxtasis es la fascinación ante la imagen, el abandono a la visión, un como confluir de todas las corrientes de la vida en el mar infinito del alma. Las imágenes surgen a veces solitarias, a veces consteladas, a veces inmóviles, a veces cambiantes, pero siempre llenan el espacio del éxtasis de una misteriosa plenitud y dominan, incontestadas y absolutas, desde su impalpable inconsistencia o desde su estelar lejanía.

Las cosas se yuxtaponen en el espacio, se separan, se reunen pero nunca se fusionan, ni se transforman, ni se pierden las unas en las otras. Las cosas tienen siempre su "en si" separado, impenetrable. Las imágenes en cambio pueden fusionarse, transformarse perderse las unas en las otras, y el alma en que aparecen puede también perderse en ellas, liberarse por virtud de su fascinación del imperio geométrico y glacial de las cosas. La visión, es decir la presencia de la imagen tiene una maravillosa potencia de absorción en cuya virtud el contemplador se funde en la irradiación de la imagen como en una llama. Este fenómeno no sólo lo experimentan los místicos sino que lo describen y proclaman los artistas considerándolo como una forma sa- 
grada de la vida. El éxtasis, en suma, ya seat religioso, ya sea artístico, es siempre la liberacion de las cusas. lat stibitat proyección del alma en una come nueva dimensión de lo real.

A una nutever esferan, en que las distancias se berran, los límites se pierden y sólo quedan en el espacio nocturno del almá la imagen y su misteriosá irradiación.

Los sucños, es decir las imátgenes gratuitas quc pucblan el espacio nocturno, son visiones extáticas. Ellas nos sumergen en un mundo primitivo y nos devuelven a la comunión prehistórica del hombre con la realiclad en cuanto a imagen.

Entre los sueños nace el mito como una fosforescente condensación cle la atmósfera del alma. Y asi fulge en la noche primitiva hasta que un día incoloro viene a apagar conjuntamente asi las tinieblas profundas como las luces sagradas de la noche.

El sol dela mañana no sólot disipa las tinieblas, también apaga las estrellasirute son las lámparas misticas del alma.

Asistir a la germinación del mito sería unn admirable privilegio. Pero no es posible. Sólo podemos asistir a la revelación de la vida, pero nunca al misterio de su preparación, nunca al laboratorio de su alquimia, nunca a la zona de lo que no se ve. Y es que la vida es, en lo absoluto de su realidad, secreto. El intelecto puede conocer la estructura invisible de las cosas, el éxtasis puede ver la fulguración de 
las imágenes, pero nadie puede violar el secreto de la vida. Por eso los verdaderamente fieles a la vida son los que la aceptan, la aman y la riven sin intentar explorar sus abismos.

En este sentido el mundo de las plantas es el mundo más fiel, más interior a la vicla. La planta vive interiormente a la vida; no le pregunta, no le interroga, no se emancipa cle ella para conocerla, ni mucho menos para utilizar en servicio de fines separados las fuerzas de la vida. Por eso la planta es auténtica. Nada es en ella construído, artificial, arbitrario y así en la planta, desde las raíces que en la sombra succionan el jugo maternal de la tierra hasta el fruto que el sol madura, todo tiene la misma frescura, y en todo pulsa la misma palpitación vital.

Es lo que comprendieron profundamente los antiguos quienes hicieron de la planta el símbolo de toda vida. Los escandinaros se la representaban en la figura del árbol Igdrásil cuyas raíces se hunden en lo más profundo del reino. de la muerte y cuyo ramaje cubre todo el universo, y los griegos, incluyendo en el concepto de la regetación así la vicla animal como la humana, hicieron que las"mismas grandes divinidades agrarias: Demeter, Dionisios presidieran conjuntamente, con el misterio de la germinación vegetal, el cle todo lo que alienta y vive.

En toda vida hay una esencia vegetal: he ahí la profunda intuición de los antiguos. Una esencia vegetal, es decir una eterna posibilidad de floración, de una constante renovación de formas, que aparecen, pasan y desaparecen impulsaclas por una inspiración fundamental que al par que las multiplica, las condiciona y las limita. El hombre, como ser viviente, encierra también una esencia vegetal, y así su vicla se da como un aparecer y renovarse de formas que obe- 
decen a una secreta inspiración. Su cuerpo crece como un árbol y su alma no es sino la atmósfera doncle nace, se multiplica y se extingue la floración de las imágenes.

El mito es una imagen que en el espacio del alma fulge desde una inalcanzable lejanía. $Y$ esa lejanía es uni cierta región del pasado, en cicrto modo anterior al tiempo y donde se realiza el éxtasis primario, el contacto inicial del hombre con el mundo de lá visión. Con el mito se expresa la absorción del hombre en el suceño vital del cosmos, más exactar. mente en el seno germinal de la naturalezat donde nace, muere y resucita lá vegetáción. Por eso es la manitestación visible de la esencia vegretal de la vicla.

E1 mito es una imagen primurdial y radiante. Primordial, no sólo porque inicia la historia del almá, sino porcue es la imagen suprema, el paradigna visible que desde el fondo del pasado vierte su luz. Y es radiante no sólo porque es luminosa sing porque, comparable al sol que junto con su luz difuncle en el espacio fisico la vida, asi la imagen mítica difunde a través de los espacios del tiempo que son los espacios del alma, la vicla y la ilusión.

El mito no es una obra cle fabricación y como tal acabado, inerte sino que es la revclación visible, espontánea, directa de la vida. Por eso vive, es decir engendra y cambia al par que se conserva y mantiene la ley fundamental de su forma. El mito tiene la fidelidad de la planta para con la actividad misteriosa que la crea. $\mathrm{Y}$ así su reino es el reino vegetal del espíritu. 


\section{- I3 -}

Las imágenes del arte - especialmente las de la poesía - son como las imágenes del mito, fosforescencias que atraviesan la atmósfera del alma, y como aquellas, propagan con su luz y su magia la palpitación primordial de la vida. Si se nos permitiera esta comparación diríamos que las imágenes del arte son las chispas errátiles desprendidas de la llama central de las visiones míticas. $Y$ agregaríamos que todas las imágenes se apagan cuando el puro conocimiento racional - aliado de la técnica - vierte clescle su implacable zenit su clariclad incolora. Porque el conocimiento racional es sin ducla claridad, pero tan sólo claridad abstractiva, esquemática - la paradójica claridad de lo invisible - hostil a la visión de las presencias vivientes, de los fantasmas fúlgidos, de las sombras simbólicas que pueblan el mundo del mito, del arte, de los sueños.

Las imágenes son, aparentemente, pura superficie, mas en ellas pulsa la obscura profundidad del todo. Dispersas, fugaces, viven sin embargo en una única atmósfera vital; liminosas, brillan como estrellas en la noche; etéreas, brotan como las hojas dellos áboles del seno maternal de la trerra. Por eso las visiones gratuitas, errantes, inconsistentes que el hombre de hoy desdeña - prisionero en sus esquemas abstractos, en sus ocupaciones urgentes, en esa triste vida urbana en fin que como dice Abel Bonnard "deja apenas aparecer las estaciones" - son al par que una liberación y una elevación, un llamado trascendente hacia la misteriosa y fecunda hondura de la vida, que es el alma.

Mariano Iberico. 